\title{
PERAN PERUBAHAN IKLIM TERHADAP KEMUNCULAN OPT BARU
}

\section{ROLE OF CLIMATE CHANGE IN THE EMERGENCE OF NEW PESTS}

\author{
Farriza Diyasti ${ }^{*}$, Aceu Wulandari Amalia ${ }^{2}$ \\ 1)Direktorat Perlindungan Perkebunan-Ditjenbun \\ Kampus Kementan Jl. Harsono RM No. 3, Gedung C Pasar Minggu, Jakarta 12550, Indonesia \\ 2)IPB University \\ Kampus IPB Dramaga Bogor Jl. Raya Dramaga, Jawa Barat 16680, Indonesia
}

*Corresponding email: riza.diyasti@gmail.com

\begin{abstract}
ABSTRAK
Organisme Pengganggu Tumbuhan (OPT) merupakan salah satu faktor pembatas penurunan produksi komoditas perkebunan. Perubahan iklim akibat pemanasan global berperan dalam memicu eksistensi OPT di alam. Fluktuasi suhu dan kelembaban udara mampu menstimulasi pertumbuhan dan perkembangan OPT. Perubahan ini dapat memengaruhi status OPT di lapangan. Isu munculnya hama baru Spodoptera frugiperda, penyakit Pestalotiopsis sp. pada karet, dan hama Pseudotheraptus sp. pada kelapa menjadi contoh OPT yang berkembang akibat adanya peran perubahan iklim global. Dengan demikian diperlukan informasi dan langkah antisipasi terhadap perubahan iklim yang terjadi untuk meminimalisir kerugian akibat serangan OPT tersebut. Adapun beberapa langkah yang dapat ditempuh antara lain membangun sistem peringatan dini, adanya kelembagaan yang tepat dan akurat, mengembangkan model tentang prediksi iklim dan OPT, serta penerapan sistem budidaya tanaman yang sehat dan diintegrasikan dalam teknologi pengelolaan hama dan penyakit tanaman secara terpadu.
\end{abstract}

Kata Kunci: iklim; OPT; Pestalotiopsis; Pseudotheraptus; Spodoptera

\begin{abstract}
Plant Pest Organisms are one of the limiting factors for the decline in the production of plantation commodities. Climate change due to global warming plays a role in triggering the existence of pests in nature. Fluctuations in temperature and humidity are able to stimulate the growth and development of pests. These changes can affect the pest's status on the ground. The issue of the emergence of a new pest, Spodoptera frugiperda, Pestalotiopsis sp. on rubber, and Pseudotheraptus sp. in coconut is an example of a pest that has developed due to the role of global climate change. Thus, information and steps to anticipate climate change are needed to minimize losses due to pest attacks. There are several steps that can be taken, such asbuilding early warning systems, establishing appropriate and accurate institutions, developing climate prediction and pests modeling, and implementing a healthy crop cultivation system and integrated into integrated pest and plant disease management technologies.
\end{abstract}

Keywords: climate; pests; Pestalottiopsis; Pseudotheraptus; Spodoptera

\section{PENDAHULUAN}

Iklim merupakan unsur utama yang berpengaruh dalam sistem metabolisme dan fisiologi tanaman. Fluktuasi suhu dan kelembaban udara

$\begin{array}{lcr}\begin{array}{l}\text { yang semakin } \\ \text { menstimulasi }\end{array} & \text { meningkat } & \text { mampu } \\ \text { perkembangan } & \text { OPT } & \text { (Organisme } \\ \text { Penganggu } & \text { Tumbuhan) } & \text { sehingga } \\ \text { berdampak buruk terhadap pertanian di }\end{array}$


Indonesia (Iwantoro, 2008). Salah satu aspek yang dipengaruhi oleh perubahan iklim yaitu keberadaan musuh alami yang juga berperan memengaruhi dinamika populasi hama. Penurunan populasi musuh alami membuat populasi hama meningkat dan tidak menutup kemungkinan adanya perubahan status serangga yang dahulunya tidak sebagai hama utama menjadi hama utama karena adanya kompetisi perebutan sumber makanan sebagai proses memertahankan keberlangsungan hidupnya. Di samping itu, perubahan iklim juga berimplikasi terhadap munculnya ras, strain, biotipe, genome baru dari OPT.

Isu serangan OPT perkebunan yang menjadi perhatian akhir-akhir ini yaitu hama Spodoptera frugiperda yang memiliki inang utama jagung namun juga dapat menyerang komoditas perkebunan (Nonci et al., 2019), penyakit Pestalotiopsis sp. pada karet (Febbiyanti \& Fairuza, 2020) dan hama Pseudotheraptus sp. pada kelapa (Ditlinbun, 2021a) menjadi contoh OPT yang berkembang akibat adanya peran perubahan iklim global. Fakta tersebut menunjukkan adanya kaitan perubahan iklim dengan masalah OPT di Indonesia. Namun, untuk memahami masalah secara menyeluruh perlu pengkajian khusus dan mendalam tentang dampak iklim terhadap perubahan dinamika OPT, sehingga dapat dirumuskan langkah antisipasi yang tepat, baik oleh pemerintah maupun masyarakat. Tulisan ini bertujuan untuk memberikan informasi mengenai pengaruh iklim terhadap perkembangan OPT serta munculnya hama baru yang berpotensi merugikan bagi ketahanan sub sektor perkebunan.

\section{METODE PENELITIAN}

Tulisan ini disusun menggunakan metode deskriptif untuk mengumpulkan, merumuskan, serta menjelaskan secara terperinci dan sistematis mengenai pengaruh iklim terhadap perkembangan OPT. Pengumpulan bahan informasi berasal dari berbagai media, elektronik (internet), jurnal, dan buku.

\section{HASIL DAN PEMBAHASAN}

\section{Hubungan unsur iklim terhadap OPT}

Perkembangan OPT bersifat dinamis dan sangat dipengaruhi oleh lingkungan biotik dan abiotik, baik secara langsung maupun tidak langsung. Pada dasarnya semua organisme dalam keadaan seimbang di alam, dengan adanya perubahan iklim dan beberapa campur tangan manusia dalam pola budidaya tanaman memengaruhi dinamika perkembangan OPT. Pengaruh perubahan iklim terhadap populasi OPT sulit diprediksi, karena adanya keseimbangan antara OPT dengan 
tanaman inang (host), serta musuh alaminya.

Spesies dari suatu wilayah yang masuk ke wilayah baru (invasif) cenderung memiliki kemampuan penyebaran yang tinggi, pertumbuhan yang cepat dengan waktu generasi yang singkat, dan toleransi yang tinggi terhadap kondisi lingkungan. Hal ini yang membuat spesies invasif sukses berkembang di wilayah yang baru (Finch et al., 2021). Adaptasi yang cepat terhadap iklim lokal dapat mendukung penyebaran spesies invasif di awal perkembangan (Colautti \& Barrett, 2013). Finch et al. (2021) menyatakan sebanyak 15\% dari semua invasif spesies beradaptasi dengan kondisi iklim yang tidak pernah terjadi di wilayah asalnya. Hal ini memengaruhi beberapa aspek, diantaranya yaitu efek langsung terhadap fisiologi, pertumbuhan, dan pertahanan hidup; efek tidak langsung secara biologi yang mengubah ketersediaan sumber daya, persaingan, herbivora, penyakit, dan ketahanan terhadap manajemen manusia, serta efek tidak langsung secara sosial yang dapat mengubah nilai sumber daya yang dipengaruhi oleh spesies invasif (Finch et al., 2021).

Distribusi dan kelimpahan serangga menanggapi dengan cepat pertahanan dan toleransi tanaman inang, serta interaksi yang melibatkan musuh alami, pesaing, dan mutualis serangga dan patogen (Weed et al., 2013). Perubahan iklim berdampak pada distribusi geografis dan dinamika populasi serangga hama, sehingga perubahan iklim akan memengaruhi status hama dalam suatu pertanaman (Wardani, 2017). Dalam hal peningkatan populasi, serangga diuntungkan pada suhu yang lebih tinggi dikarenakan kematangan reproduksi lebih singkat dan terjadinya peningkatan dalam kualitas makanan akibat cekaman abiotik pada tanaman budidaya (White, 2017). Susanti et al. (2011) melaporkan keberadaan hama-hama dominan baru yang sebelumnya belum pernah muncul pada bawang merah. Perubahan status hama dominan diperkirakan terjadi akibat peningkatan suhu udara (Magina et al., 2011).

Beberapa spesies invasif sensitif terhadap perubahan waktu, jumlah curah hujan, dan perubahan suhu sekitar atau kelembaban, sedangkan yang lain lebih responsif terhadap perubahan tekanan yang terjadi pada inang (Finch et al., 2021). Tanaman yang mengalami cekaman cenderung rentan terhadap serangan patogen. Kondisi panas namun sedikit lembab di malam hari dengan kisaran suhu $30-31^{\circ} \mathrm{C}$ merupakan kondisi yang mendukung perkembangan cendawan luka api (Sporisorium scitamineum), ditambah lagi jika telah 
mengalami kepras lebih dari tiga kali akan lebih mudah terserang penyakit ini (Nurindah \& Yulianti, 2018).

Hasil kajian Ghini et al. (2011) menunjukkan peningkatan kejadian iklim ekstrim sebagai salah satu dampak perubahan iklim meningkatkan perkembangan OPT tanaman perkebunan dengan tingkat kehilangan produksi global $10 \%$.

\section{Pendugaan munculnya OPT baru akibat perubahan iklim global}

\section{Hama Spodoptera frugiperda (Lepidoptera: Noctuidae)}

Di awal tahun 2019, ulat grayak jenis Spodoptera frugiperda muncul di Indonesia. $S$. frugiperda atau lebih dikenal dengan ulat grayak frugiperda merupakan hama tanaman jagung yang selama ini berkembang biak di Benua Amerika bagian Tengah yang memiliki iklim tropis. Kemudian S. frugiperda menyebar ke Afrika, India, Thailand, Cina, Myanmar dan Indonesia (CABI, 2019). Saat musim semi, S. frugiperda akan migrasi ke Utara dengan kemampuan terbang hingga $100 \mathrm{~km}$ dalam satu malam. Dengan bantuan angin, S. frugiperda mampu memencar sejauh $500 \mathrm{~km}$ di Amerika Tengah, dan 1.700 km dari Mississippi ke Canada dalam waktu 30 jam sebelum meletakkan telur (Westbrook et al., 2016). Pada kondisi hangat, ngengat $S$. frugiperda betina mampu menghasilkan hingga
2000 butir telur dalam satu siklus hidupnya (Nonci et al., 2019). Selain karena bermigrasi, diduga telur atau larva hama ini dapat juga terbawa pada komoditas yang diperdagangkan (sayuran, buah, atau tanaman hias) yang dikirim dari AS ke Eropa dengan transportasi udara. Jalur pemencaran dari daratan Asia ke Indonesia diduga karena tiupan Angin muson Barat pada Bulan Oktober-April (Cock et al., 2017). Menurut Early et al. (2018) hama ini diduga dapat dengan mudah menyebar ke belahan dunia lain dikarenakan adanya kesesuaian iklim, rute perdagangan dan rute penumpang.

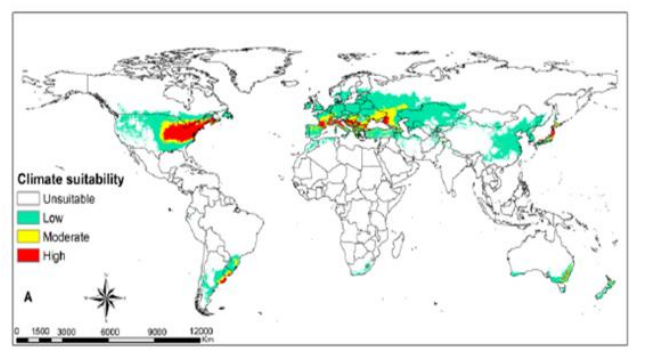

Gambar 1. Kesesuaian iklim S. frugiperda secara global (Teppa Yotto et al., 2021)

Laporan dari Grow Asia (2020) menunjukkan $S$. frugiperda di Indonesia telah tersebar di 25 Provinsi. $S$. frugiperda memiliki kisaran inang yang sangat luas, dapat menyerang lebih dari 80 spesies tanaman, diantaranya jagung, padi, sorgum, jewawut, tebu, sayuran, dan kapas (Nonci et al., 2019). Jika tanaman inang utama tidak tersedia, $S$. frugiperda dapat bertahan pada 
pertanaman rumput-rumputan (Da Silva et al., 2017). Pada masa pembungaan, serangan $S$. frugiperda lebih rendah dibandingkan saat tanaman masih muda, hal ini disebabkan karena ketahanan tanaman lebih tinggi saat masa generatif dengan adanya dukungan pemupukan dan pengolahan tanah yang baik oleh petani (Mamahit et al., 2020). Terdapat 2 strain S. frugiperda yaitu Strain C (corn strain) yang menyerang jagung, sorgum, dan kapas; Strain R (rice strain) yang menyerang jagung, padi, dan rerumputan. Kedua strain dijumpai di Afrika (Cock et al., 2017), India (Swamy et al., 2018), dan diduga strain yang sama dijumpai juga di Indonesia (Lestari et al., 2020). Hasil identifikasi Sartiami et al. (2020) menunjukkan spesies ulat grayak frugiperda yang ditemukan di Provinsi Banten merupakan strain R. Ciri-ciri larva $S$ frugiperda secara morfologis yaitu, memiliki garis berwarna cerah di sub dorsal tubuh, garis berwarna pucat di dorsal tubuh, garis tebal seperti pita di bagian lateral tubuh, dan pada segmen terakhir abdomen terdapat 4 titik hitam membentuk segi empat. Pada bagian kepala terdapat garis membentuk huruf Y terbalik, yang membedakannya dengan jenis $S$. litura (Ditlinbun, 2019b). Kehilangan hasil atas serangan $S$. frugiperda antara 30-60\%, dan memiliki kerakusan dalam makan tanaman hingga
10 kali lipat dibanding spesies lokal (Spodoptera litura) (Sari, 2020).

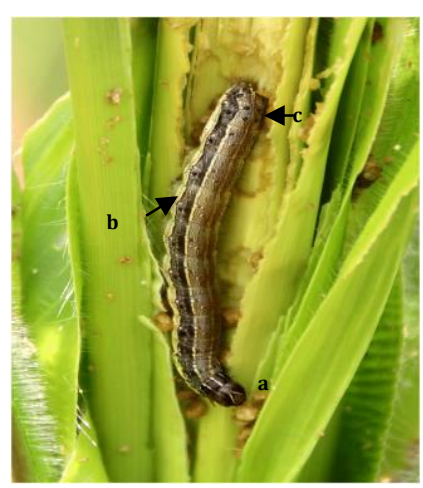

Gambar 2. Larva $S$. frugiperda instar-5 dengan ciri khas (a) huruf " $\mathrm{Y}$ " terbalik pada kepala, (b) garis tebal gelap pada lateral tubuh, (c) terdapat 4 titik pinacula pada abdomen-8 dengan seta tunggal (Goergen et al., 2016)

Mamahit et al., (2020) menemukan S. frugiperda pada daerah pertanaman jagung yang tumbuh pada ketinggian 700 sampai $800 \mathrm{~m}$ dpl, sejalan dengan Maharani et al. (2019) bahwa ketinggian tempat berpengaruh terhadap keberadaan hama $S$. frugiperda, pada ketinggian lebih dari $850 \mathrm{~m}$ dpl tidak ditemukan hama tersebut. S. frugiperda merupakan hama invasif yang tidak mampu hidup pada dataran tinggi (Wang et al., 2020). Feldmann et al. (2019) menemukan bahwa $S$. frugiperda tidak memiliki kemampuan diapause, sehingga siklus perkembangan hidupnya sangat dipengaruhi suhu lingkungan. Pada suhu rendah, mortalitas S. frugiperda lebih rendah, namun pada kisaran suhu tertentu, kapasitas reproduksi ngengat betina meningkat dengan peningkatan 
suhu (Schlemmer, 2018). Ketika suhu mulai naik, S. frugiperda akan kembali berkembang, menghasilkan larva dan menginvasi daerah baru dengan kisaran suhu 20-30 ${ }^{\circ} \mathrm{C}$ (Baloch et al., 2020). Selain faktor suhu, Baloch et al. (2020) juga mengemukakan pengaruh kelembaban relatif dan curah hujan berperan dalam distribusi S. frugiperda (Gambar 3).

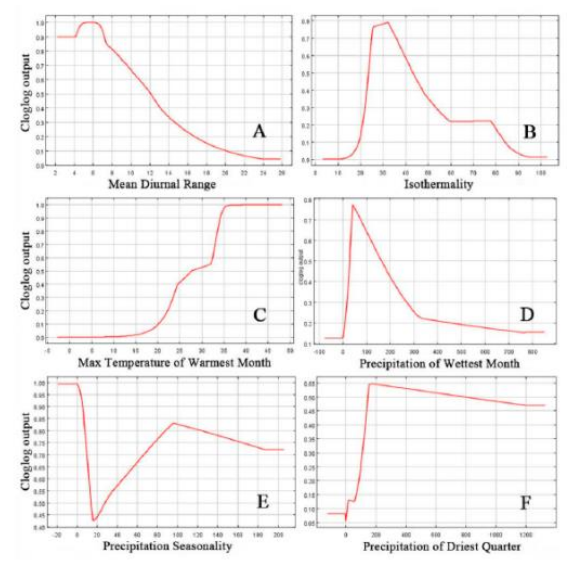

Gambar 3. Pengaruh suhu, curah hujan, dan kelembapan terhadap $S$. frugiperda (Baloch et al., 2020)

Secara keseluruhan, kesesuaian $S$. frugiperda berada pada rentang suhu 6$35{ }^{\circ} \mathrm{C}$, curah hujan bulan terbasah sebesar $45 \mathrm{~mm}$, dan curah hujan kuartal terkering sebesar $180 \mathrm{~mm}$ dengan curah hujan musiman nol (Baloch et al., 2020). Untuk mencegah perluasan daerah serangan hama lebih lanjut, impor pertanian dan upaya pengelolaan harus dilakukan secara komperhensif dengan peran kelembagaan yang kuat.

\section{Hama Pseudotheraptus sp. pada kelapa}

Lampiran Peraturan Menteri Pertanian Republik Indonesia Nomor
31/PERMENTAN/KR.010/7/2018

Tentang Perubahan Kedua Atas

Peraturan Menteri Pertanian Nomor 93/PERMENTAN/OT.140/12/2011

tentang Jenis Organisme Pengganggu Tumbuhan Karantina, hama Pseudotheraptus sp. (Hemiptera: Coreidae) merupakan hama golongan II kategori A1. Penyebarannya terdapat di Kenya, Afrika Selatan, dan Tanzania, dan belum dilaporkan ada di Indonesia. Namun berdasarkan informasi dari Balai Penelitian Palma, Pseudotheraptus wayi ditemukan menyerang pertanaman kelapa di Provinsi Sulawesi Utara, di Mapanget pada pertengahan tahun 2019. Serangan P. wayi pada buah kelapa muda menyebabkan abortus buah dan bentuk buah abnormal, akibatnya petani dapat kehilangan hasil produksi hingga 50\% (Lumentut, 2021).

Kepik P. wayi menyerang titik tumbuh tunas, bunga (menyebabkan kelopak bunga gugur) dan buah (menyebabkan bentuk abnormal, lubang, bercak cokelat hingga kehitaman, mengeluarkan eksudat seperti getah). Pada kelapa, nimfa muda memakan pangkal bunga jantan, dan nimfa yang lebih tua/dewasa memakan bunga betina yang sedang berkembang. Cairan saliva dari hama $P$. wayi memiliki kandungan racun yang diinfestasikan ke dalam jaringan buah sehingga menimbulkan gejala bercak kehitaman dan 
buah mudah gugur sebelum waktunya (CABI, 2020).

Perpindahan serangga ini diduga adanya bantuan angin dan dipicu oleh perubahan suhu. $P$. wayi memiliki kisaran inang yang luas, diantaranya buah jambu, alpukat, jambu mete, kelapa sawit dan kelapa (Peter, 2013). Menurut Soesanthy \& Trisawa (2011), P. wayi merupakan serangga fitofag yang berasosiasi dengan tanaman jambu mete di Indonesia, namun tidak sebagai hama utama. Kajian yang dilakukan Safitri et al. (2020), serangga Hemiptera dengan spesies terbanyak ditemukan pada ekosistem kelapa sawit, dan berperan sebagai herbivora. Hal ini dikarenakan faktor eksternal yang mendukung yakni pada ekosistem tersebut terdapat gulma yang menjadi sumber makanan bagi, serta kesesuaian kondisi iklim juga sangat memengaruhi perkembangan hama ini. Menurut Lumentut (2021), penggunaan pestisida secara serampangan mengakibatkan hama ini semakin berkembang lebih baik karena timbulnya fenomena resistensi, resurgensi maupun terbunuhnya musuh alami hama ini. $P$. wayi dapat dikendalikan oleh serangga Hymenoptera seperti Anoplepis custodiens, Oecophylla langinoda, dan Oencyrtus sp. Dengan demikian manipulasi lingkungan sangat diperlukan untuk menekan populasi hama
(Lumentut, 2019). Pengkajian lebih lanjut diperlukan untuk mengetahui bioekologi dan dinamika populasi hama ini untuk selanjutnya dapat ditempuh langkah pengendalian yang efektif.

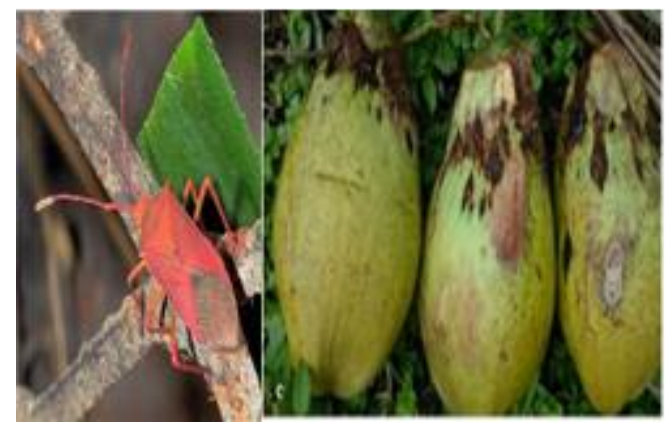

Gambar 4. Imago P. wayi (CABI, 2020), dan gejala serangan berupa bercak lesi kehitaman pada buah kelapa (Lumentut, 2021)

\section{Penyakit gugur daun Pestalotiopsis sp. pada karet}

Menurut Febbiyanti (2020), penyakit gugur daun yang disebabkan oleh Pestalotiopsis sp. pada karet dilaporkan pertama kali terjadi di Malaysia pada tahun 1975 di kebun pembibitan dan menyerang lagi tahun 2017. Di Indonesia, pertama kali terjadi di wilayah Sumatera Utara pada tahun 2016, selanjutnya menyebar ke daerah Sumatera Bagian Selatan pada akhir 2017 hingga sekarang, serangan mencapai lebih dari 300.000 ha, dengan kehilangan hasil yang ditimbukan mencapai 27\% (Ditlinbun, 2021b).

Penyakit Pestalotiopsis Leaf Spot Diseases sebelumnya dijumpai di pertanaman kelapa sawit. Cendawan ini merupakan patogen lemah yang 
menyerang tanaman inang dikarenakan adanya pelukaan akibat serangan hama ulat sebelumnya ataupun patogen utama (Martinez \& Plata-Rueda, 2013). Pestalotiopsis sp. menyerang daun tua yang sebelumnya diduga telah terserang patogen gugur daun lainnya seperti Oidium sp., $\quad$ Colletotrichum sp., Corynespora sp, dan Fusicocum sp. Spora cendawan (konidium) dengan mudah disebarkan oleh angin, bahkan untuk jarak dekat spora dapat terbawa oleh percikan air dan serangga (Douira et al,. 2014). Dengan adanya kondisi iklim yang sesuai, patogen ini dapat berkembang dengan cepat. Infeksi Pestalotiopsis sp. akan semakin parah pada curah hujan >300 mm/bulan dengan kelembaban rata-rata $>80 \%$ (Febbiyanti \& Fairuza, 2020). Gejala penyakit pada daun ditunjukkan oleh bintik coklat, kemudian berkembang menjadi bercak coklat tua dan terdapat batas yang jelas antara bagian bercak dan bagian daun yang masih sehat. Daun yang terinfeksi akan gugur sebelum waktunya, sehingga kerapatan tajuk juga semakin menurun. Sebagian ranting mati dan tajuk tanaman meranggas serta berkurang lebih dari 50 \% (Febbiyanti \& Fairuza, 2020).

Dalam menghadapi perubahan iklim dalam kaitan dengan perkembangan hama dan penyakit tanaman diperlukan beberapa langkah yang sesuai. Monitoring dan pengawasan wilayah dalam hal importasi komoditas inang merupakan gerbang awal pertahanan dalam menghindarkan dari kerusakan akibat spesies invasif (Lovett et al., 2016). Manajemen campur tangan manusia memegang peranan penting dalam mengendalikan spesies invasif yang mengacu pada pengelolaan sumber daya, kultur teknis yang tepat dengan meningkatkan pertahanan tanaman inang maupun menciptakan kondisi yang tidak sesuai untuk perkembangan OPT (Finch et al., 2021).

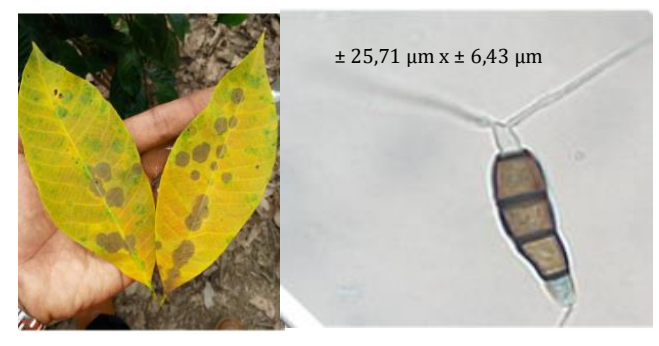

Gambar 5. Gejala serangan (kiri) dan bentuk mikroskopis Pestalotiopsis sp. (Febbiyanti \& Fairuza, 2020)

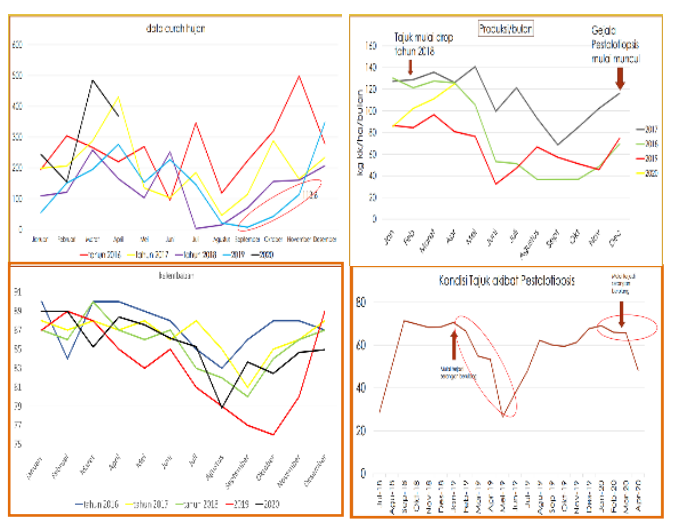

Gambar 6. Pengaruh curah hujan dan kelembapan (kiri) terhadap kerapatan tajuk karet (kanan) (Febbiyanti, 2020)

Pemahaman tentang pengaruh lingkungan abiotik akibat perubahan 
iklim terhadap interaksi tritrofik antara tanaman inang, herbivora, dan musuh alami perlu ditingkatkan, sehingga dapat dikembangkan teknik pengendalian hama terpadu (PHT) yang efektif. PHT mencakup manajemen lingkungan dengan kultur teknis, biologis dengan memanfaatkan musuh alami dan kimiawi dengan penggunaan pestisida yang bijaksana (Finch et al., 2021).

Penggunaan dan pengembangan varietas yang adaptif dan toleran terhadap cekaman lingkungan dan tahan serangan OPT sangat diperlukan meskipun membutuhkan waktu yang lama (Servina, 2019). Untuk itu diperlukan proyeksi iklim yang dapat menjadi landasan bagi penelitian dan pengembangan pemuliaan tanaman. Jika suatu daerah diproyeksi akan mengalami penurunan curah hujan maka varietas yang akan dikembangkan adalah varietas toleran kekeringan dan sebaliknya (Servina, 2019). Pengembangan suatu sistem peringatan dini OPT dengan indikator iklim, harus dibangun dengan melibatkan kepakaran bidang ilmu dan kelembagaan yang kuat berkelanjutan (Susanti et al., 2018).

\section{KESIMPULAN}

Unsur iklim berpengaruh terhadap perkembangan OPT baik secara langsung maupun tidak langsung. Perubahan iklim global memicu terjadinya distribusi spesies invasif ke wilayah lain dengan kemampuan penyebaran yang tinggi, pertumbuhan yang cepat dengan waktu generasi yang singkat, dan toleransi yang tinggi terhadap kondisi lingkungan. Dengan demikian diperlukan aksi adaptasi dan mitigasi dalam mengantisipasi serangan OPT tersebut.

Beberapa hal yang dapat dilakukan antara lain: (1) membangun sistem peringatan dini (early warning system) dengan menggalakan kegiatan monitoring dan pengamatan OPT secara intensif di lapangan; (2) meningatkan peran serta kelembagaan yang tepat dan akurat. Manajemen karantina wilayah pada jalur pemasukan barang memerlukan pengawasan yang ketat; (3). Mengembangkan model prediksi iklim yang dikaitkan dengan dinamika serangan OPT; dan (4) penerapan sistem budidaya tanaman sehat yang diintegrasikan dalam teknologi PHT yang mencakup manajemen lingkungan dengan kultur teknis (penggunaan varietas toleran), biologis dengan memanfaatkan musuh alami, dan kimiawi dengan penggunaan pestisida secara bijaksana.

\section{DAFTAR PUSTAKA}

CABI. (2019). Community-Based Fall Armyworm (Spodoptera frugiperda) Monitoring, Early Warning and Management. FAO. 
CABI. (2020). Invasive Spesies Compendium : Pseudotheraptus wayi (Coconut bugs). URL: https://www.cabi.org/isc/datashe et/45033 (diakses pada Maret 2021).

DITLINBUN. (2019a). Penyakit gugur daun karet Pestalotiopsis sp. URL: http://perlindungan.ditjenbun.pert anian.go.id/web/page/title/31997 9/penyakit-gugur-daun-karetpestalotiopsissp?post type $=$ informasi. $\quad$ (diakses pada 25 Oktober 2020).

DITLINBUN. (2019b). Waspada Spodoptera frugiperda. URL: http://perlindungan.ditjenbun.pert anian.go.id/web/page/title/31998 $0 /$ waspada-spodopterafrugiperda?post type=informasi. (diakses pada 23 Oktober 2020).

DITLINBUN. (2021a). Waspada OPT baru Pseudotheraptus wayi pada kelapa. URL:

http://perlindungan.ditjenbun.pert anian.go.id/web/page/title/34090

0/waspada-opt-baru-

pseudotheraptus-wayi-pada-

kelapa.post type=informasi.

(diakses pada April 2021).

DITLINBUN. (2021b). Teknologi remote sensing dalam mendeteksi kesehatan tanaman. URL: http://perlindungan.ditjenbun.pert anian.go.id/web/page/title/34110 9/teknologi-remote-sensingdalam-mendeteksi-kesehatantanaman-karet. (diakses pada April 2021).

Baloch, M. N., Fan, J., Haseeb, M., \& Zhang, R. (2020). Mapping Potential Distribution of Spodoptera frugiperda (Lepidoptera: Noctuidae) in Central Asia. Insects. 2020(11), 172.
Cock, M. J., Beseh, P. K., Buddie, A. G., Cafá, G., \& Crozier, J. (2017). Molecular methods to detect Spodoptera frugiperda in Ghana, and implications for monitoring the spread of invasive species in developing countries. Scientific Reports. 7(1), 4103.

Colautti, R. I., \& Barrett, S. C. H. (2013). Rapid adaptation to climate facilitates range expansion of an invasive plant. Science. 342(2013), 364-366.

Da Silva. (2017). Biology and nutrition of Spodoptera frugiperda (Lepidoptera: Noctuidae) fed on different food sources. Sci. agric. 74(1), 18-31.

Douira, A. (2014). Study of Pestalotiopsis palmarum pathogenicity on Washingtonia robusta (Mexican palm). International journal of Pure \& Appllied Bioscience. 2 (6), 138145.

Early, R., Moreno, P. B., Nurphy, S. T., \& Day, R. (2018). Forecasting the global extent of invasion of the cereal pest Spodoptera frugiperda the fall army worm. J NeoBiota 40(2018), 25-50.

Febbiyanti, T. R. (2020). Seri Diskusi Teknis Karet: Epidemi dan pengendalian penyakit gugur daun pestalotiopsis pada tanaman karet. URL:

http://www.puslitkaret.co.id/wpcontent/uploads/2020/05/Tri-

Rapani-Febbiyanti.-Webinar.PPK.pdf (diakses pada Maret 2021).

Febbiyanti, T. R., \& Fairuza, Z. (2020). Identifikasi penyebab kejadian luar biasa penyakit gugur daun karet di Indonesia. Jurnal Penelitian Karet. 37 (2), 193-206. doi: 
https://doi.org/10.22302/ppk.jpk. v37i2.616.

Feldmann, F., Rieckmann, U., \& Winter, S. (2019). The spread of the fall armyworm Spodoptera frugiperda in Africa-What should be done next?. J. Plant Dis. Protect. 126(2019), 97-101.

Finch, D. M. (2021). Effects of Climate Change on Invasive Species. Invasive Species in Forests and Rangelands of the United States pp 57-83. URL: https://link.springer.com/chapte r/10.1007/978-3-030-45367-1 4 pada Mei 2021

Ghini, R., Hamada, E., Pedro Júnior, M. J., Marengo, J. A., \& Gonçalves, R. R. V. (2008). Risk analysis of climate change on coffee nematodes and leaf miner in Brazil. Pesquisa agropecuária brasileira. 43(2008), 187-194.

Goergen, G,. Kumar, L., Sankung, S. B,. \& Tamo, M. (2016). First report of outbreaks of the fall armyworm Spodoptera frugiperda (J E Smith) (Lepidoptera, Noctuidae), a New Alien Invasive Pest in West and Central Africa. Research gate.

Grow Asia. (2020). ASEAN action plan on fall Armyworm control. URL: https://exchange.growasia.org/ase an-action-plan-fall-armywormcontrol (diakses pada Mei 2021).

Iwantoro, S. (2008). Pengaruh perubahan iklim global terhadap eksistensi spesies invasif dan perdagangan global. Prosiding Seminar Nasional PEI dan PFI Komda Sumsel. Palembang, 18 Oktober 2008.

Lestari, I. (2020). Identification and genetic diversity of Spodoptera frugiperda in Lampung Province,
Indonesia. Biodiversitas. 21(4), 1670-1677. DOI: 10.13057/biodiv/d210448.

Lumentut, N. (2021). Mengenal hama perusak buah kelapa, Pseudotheraptus wayi (Hemiptera: Coreidae). Info Perkebunan. URL: Infotekbun-Knowing the Pests Destroying Coconut Fruits P. wayi (diakses pada Maret 2021).

Lovett, G. M., Weiss, M., \& Leibhold, A. M. (2016). Nonnative forest insects and pathogens in the United States: impacts and policy options. Ecol Appl. 26(2016), 1437-1455.

Magina, F., Makundi, R., Maerere, A., Maro, G., \& Teri, J. (2011). Temporal variations in the abundance of three important insect pests of coffee in Kilimanjaro region, Tanzania. In: Proc 23rd International Scientific Colloquium on Coffee. Association Scientifique Internationale du Caffe (ASIC), Bali Indonesia, Oktober 3-8, 2010. p.1114-1118.

Maharani, Y., Dewi, V. K., Puspasari, L. T., Riszkie, L., Hidayat, Y., \& Dodo. D. (2019). Cases of Fall Army Worm Spodoptera frugiperda J. E. Smith (Lepidoptera: Noctuidae) Attack on Maize in Bandung, Garut and Sumedang District, West Java. J Cropsaver. 2(1), 38-46.

Mamahit, J. M. E., Manueke, J., \& Pakasi, S. E. (2020). Infasive pests fall army worm spodoptera frugiperda (J.E. Smith) on maize in minahasa district. In: Herlinda S et al. (Eds.), Prosiding Seminar Nasional Lahan Suboptimal ke-8 Tahun 2020, Palembang 20 Oktober 2020. pp. 616-624. Palembang: Penerbit \& Percetakan Universitas Sriwijaya (UNSRI). 
Martinez, L. C., \& Plata-Rueda, A. (2013). Lepidoptera vectors of Pestalotiopsis fungal disease: first record in oil palm plantations from Colombia. International Journal of Tropical Insect Science. 33(4), 239246.

Nurindah \& Yulianti, T. (2018). Strategi pengelolaan serangga hama dan penyakit tebu dalam menghadapi perubahan iklim. Buletin Tanaman Tembakau, Serat \& Minyak Industri. 10(1), 39-53. DOI:10.21082/btsm.v9n1.2018.3954.

Nonci. (2019). Pengenalan fall armyworm (Spodoptera frugiperda JE Smith) hama baru pada tanaman jagung di indonesia. Makassar: Balai Penelitian Tanaman Serealia.

Peter, E. J. (2013). Morphology, biology and semiochemical mediated behaviour of the coreid bug Pseudotheraptus wayi Brown 1955, a major pest of cashew in East Africa. Thesis. Crop scienceMakerere University.

Safitri, D., Yaherwandi, \& Efendi, S. (2020). Keanekaragaman serangga herbivora pada ekosistem perkebunan kelapa sawit rakyat Di Kecamatan Sitiung Kabupaten Dharmasraya. J Menara Ilmu. 16(1), 19-28.

Sari, K. K. (2020). Viral Hama Invasif Ulat Grayak (Spodoptera frugiperda) Ancam Panen Jagung di Kabupaten Tanah Laut Kalsel. J. Proteksi Tanaman Tropika. 3(3), 244-247.

Sartiami, D., Dadang., Harahap, I. S., Kusumah, Y. M., \& Anwar, R. (2020). First record of fall armyworm (Spodoptera frugiperda) in Indonesia and its occurence in three provinces. IOP Conf. Series: Earth and Environmental Science.
$468 \quad$ (2020), 012021.

doi:10.1088/1755-

1315/468/1/012021.

Servina, Y. (2019). Dampak perubahan iklim dan strategi adaptasi tanaman buah dan sayuran di daerah tropis. J Litbang Pertanian. 38(2), 65-76.

Schlemmer, M. E. (2018). Temperature on Development and Reproduction of Spodoptera frugiperda (Lepidop: Noctuidae). North-West University: Evanston, IL, USA, 2018; pp. 1-103.

Soesanthy, F., \& Trisawa, I. M. (2011). Pengelolaan serangga-serangga yang berasosiasi dengan tanaman jambu mete. Buletin RISTI. 2 (2), 221-230.

Surmaini, E., \& Faqih, A. (2016). Kejadian Iklim Ekstrem dan Dampaknya Terhadap Pertanian Tanaman Pangan di Indonesia. Jurnal Sumber Daya Lahan. $10(2), 115-128$.

Susanti, E., Surmaini, E., \& Sarvina, Y. (2011). Dinamika organisme penggangu tumbuhan (OPT) dominan pada pertanaman bawang merah. Prosiding Seminar Sumber Daya Lahan Pertanian, Banjar Baru 13-14 Juli 2011.

Susanti, E., Surmaini, E., \& Estiningtyas, W. (2018). Parameter iklim sebagai indikator peringatan dini serangan hama penyakit tanaman. $J$ Sumberdaya Lahan. 12(1), 59-70.

Susilawati. (2004). Lalat pengorok daun Liriomyza sativae Blanchard hama baru pada beberapa sayuran dataran rendah. J. Hort. 14(4), 279286.

Swamy, H. M. M., Asokan, R., Kalleshwaraswamy, C. M., \& Deshmukh, S. (2018). Prevalance of 
"R" strain and molecular diversity of fall army worm Spodoptera frugiperda (J.E. Smith) (Lepidoptera: Noctuidae) in India. Indian Journal of Entomology. 80(3), 544-553.

Tepa, Y. (2021). Global Habitat Suitability of Spodoptera frugiperda (JE Smith) (Lepidoptera, Noctuidae): Key Parasitoids Considered for Its Biological Control. Insects 202(12), 273-289.

https://doi.org/10.3390/insects12 $\underline{040273}$.

Wang, R., Jiang, C., Guo, X., Chen, D., You, C., Mingtian, Y., \& QingLi, W. (2020). Potential distribution of Spodoptera frugiperda (J.E. Smith) in China and the major factors influencing distribution. Global Ecology and Conservation. 21(2020), 1-10.

Wardani, N. (2017). Perubahan iklim dan pengaruhnya terhadap serangga hama. Prosiding Seminar Nasional Agroinovasi Spesifik Lokasi Untuk Ketahanan Pangan Pada Era Masyarakat Ekonomi ASEAN.

Weed, A. S., Ayres, M. P., \& Hicke, J. A. (2013). Consequences of climate change for biotic disturbances in North American forests. Ecol Monogr. 83(2013), 441-470.

Westbrook, J. K., Nagoshi, R. N., Meagher, R. L., Fleischer, S. J., \& Jairam, S. (2016). Modeling seasonal migration of fall armyworm moths. Int J Biometeorol. 60(2), 255-67. doi: 10.1007/s00484-015-1022-x.

White, J. (2017). Climate change and the generational timescape. Sage Journal. 4(2017), 1-17. https://doi.org/10.1111/1467954X.12397. 